\title{
A permafrost glacial hypothesis - Permafrost carbon might help explaining the Pleistocene ice ages
}

\author{
Roland Zech
}

How to cite:

Zech, R. (2012): A permafrost glacial hypothesis - Permafrost carbon might help explaining the Pleistocene ice ages, 61 (1): 84-92. DOI: $10.3285 /$ eg.61.1.07

Abstract:

\begin{abstract}
Over the past several $\sim 100$ ka glacial-interglacial cycles, the concentration of atmospheric $\mathrm{CO}_{2}$ was closely coupled to global temperature, which indicates the importance of $\mathrm{CO}_{2}$ as a greenhouse gas. The reasons for changes in atmospheric $\mathrm{CO}_{2}$ have mainly been sought in the ocean, but remain elusive. Moreover, the mid-Pleistocene transition from the ' 41 ka world' during the early Pleistocene before $\sim 0.7 \mathrm{Ma}$ to the $\sim 100 \mathrm{ka}$ ice age cycles is poorly understood. The classical Milankovitch theory of summer insolation forcing at high northern latitudes can not fully explain the Pleistocene ice age rhythm.

Based on the recent findings that the amount of soil organic carbon stored in high-latitude permafrost regions has been greatly underestimated and the simple logic that permafrost regions and respective carbon pools were likely much larger during glacials than during interglacials, a 'permafrost glacial hypothesis' is proposed: (i) Gradual sequestration of $\mathrm{CO}_{2}$ in permafrost soils during coolings and rapid release of $\mathrm{CO}_{2}$ and methane during terminations, respectively, provide important positive feedbacks for the climate. (ii) Integrated annual insolation at the southern and thus most sensitive permafrost boundary may act as a trigger for global climate changes. (iii) The mid-Pleistocene transition might be readily explained with permafrost extents reaching $\sim 45^{\circ} \mathrm{N}$ during the long-term Pleistocene cooling, resulting in a transition from high-latitude obliquity ( $\left.\sim 41 \mathrm{ka}\right)$ to mid-latitude eccentricity $(\sim 100 \mathrm{ka})$ forcing.
\end{abstract}

\section{Eine Permafrost Hypothese - Kohlenstoff in Permafrostböden könnte helfen, die pleistozänen Eiszeiten zu erklären}

Kurzfassung:

Während der letzten $\sim 100$ ka Glazial-Interglazial-Zyklen war die Konzentration des Treibhausgases $\mathrm{CO}_{2}$ in der Atmosphäre eng mit der globalen Temperatur gekoppelt. Die Gründe für die $\mathrm{CO}_{2}$ Konzentrationsschwankungen wurden bislang vor allem im Ozean vermutet, bleiben aber rätselhaft. Darüberhinaus gibt es nur spekulative Erklärungsansätze für den mittelpleistozänen Übergang von den 41 ka Eiszeitzyklen im Frühpleistozän vor $\sim 0.7$ Ma zu den $\sim 100$ ka Eiszeitzyklen danach. Die klassische Milankovitch Theorie der Sommerinsolation in hohen nördlichen Breiten kann die Abfolge der pleistozänen Eiszeiten nicht vollständig erklären.

Basierend auf jüngsten Erkenntnissen, dass die Menge des organischen Bodenkohlenstoffs in Permafrostgebieten massiv unterschätzt wurde, und der simplen Logik, dass Permafrostgebiete und die entsprechende Kohlenstoffspeicherung in den Eiszeiten vermutlich wesentlich größer waren als in den Warmzeiten, soll hier eine „Permafrost Hypothese“ vorgestellt werden: (i) Langsame Anreicherung von Kohlenstoff in Permafrostböden während Abkühlungsphasen, sowie rasche Freisetzung von $\mathrm{CO}_{2}$ und Methan während Erwärmungsphasen, sind entscheidende positive Rückkopplungsprozesse für das Klima. (ii) Änderungen der integrierten annuellen Insolation an der südlichen, und damit sensitiven Permafrostgrenze könnten als externe Auslöser für globale Klimaveränderungen fungieren. (iii) Der mittelpleistozäne Wechsel der Eiszeitzyklen könnte implizit damit erklärt werden, dass Permafrostgebiete im Laufe der langfristigen pleistozänen Abkühlung Breiten von $\sim 45^{\circ} \mathrm{N}$ erreichten. Dort verschwindet das für höhere nördliche Breiten charakteristische aus der Schiefe der Ekliptik resultierende 41 ka Signal der annuellen Insolation, und es dominiert allein das $\sim 100$ ka Signal der orbitalen Ekzentrizität.

Keywords: $\quad$ Pleistocene, ice ages, Milankovitch, insolation forcing, permafrost, Siberia

Address of author: $\quad$ R. Zech, Geological Institute, ETH Zurich, Sonneggstr. 5, 8092 Zurich, Switzerland. E-Mail: godotz@gmx.de, Phone: +44144632 2184, Fax +4144632 1080

\section{Introduction}

Recent studies have suggested that much more soil organic carbon is stored in northern permafrost regions than hitherto assumed, possibly as much as $1670 \mathrm{Pg} \mathrm{C}$ (ScHuUr et al. 2008; TARNOCAI et al. 2009). On the one hand, such high figures imply that the role of permafrost for soil organic matter preservation may have been underestimated, particularly in view of low biomass production in such cold ecosystems. On the other hand, these revised carbon pool estimates have fueled concerns that anthropogenic warming leads to thawing of permafrost, enhanced mineralization of soil organic carbon, and release of $\mathrm{CO}_{2}$ and methane into the atmosphere (KHVOROSTYANOv et al. 2008; SCHAEFER et al. 2011; SchuUr et al. 2008; Zimov, SchuUr \& Chapin III 2006). While the temperature-sensitivity of soil carbon mineralisation and the related feedbacks to climate change remain somewhat controversial on a global scale (BonDLAMBerty \& Thomson 2010; DAvidson \& JANSSENS 2006), there is little doubt that thawing permafrost will emit on the order of several hundred Pg carbon over the next few centuries, and will thus more than off-set enhanced carbon sequestration by expanding biomass (GRUBER et al. 2004; KhVorostyanov et al. 2008; Schaefer et al. 2011; SchuUR et al. 2008). It should be noted that carbon emissions from thawing permafrost are a particularly strong positive feedback mechanism, because part of the carbon is released as methane, which has a higher greenhouse gas potential 
than $\mathrm{CO}_{2}$. Permafrost carbon dynamics are thus already widely acknowledged to be important for the global carbon cycle today.

However, scientific attention has much less focused on the possible role of permafrost carbon dynamics on glacialinterglacial timescales. This largely stems from the very limited number of suitable outcrops to study past changes in permafrost carbon pools. Outcrops along the Russian Arctic coast and from Alaska rarely span more then several ten thousand years, are often heavily affected by cryoturbation and have hiati (MuHs et al. 2003; Reyes, Froese \& Jensen 2010; Schirrmeister et al. 2002; Wetterich et al. 2008). The only published permafrost profile so far that likely continuously spans two glacial cycles is the loesspaleosol sequence 'Tumara' in northeast Siberia (M. ZECH et al. 2010; ZECH, ZECH \& GLASER 2007; ZECH et al. 2008). In order to circumvent any shortcomings stemming from dating uncertainties and to obtain a direct proxy of paleotemperatures for the Tumara Sequence, we have recently analyzed the compound-specific deuterium/hydrogen ratios on extracted alkanes (R. ZECH et al. 2010; ZECH et al. 2011). The respective results now unambiguously (i.e. totally independent of the age control) corroborate that more organic carbon was sequestered at this site during glacials than during interglacials, supporting the logic that cold, glacial conditions favored intensive permafrost, water logging, and soil organic matter preservation (Fig. 1).

Although it is very challenging to up-scale the observed local permafrost carbon dynamics, several hundred $\mathrm{Pg}$ 'excess carbon' might have been stored in the vast nonglaciated plains in Siberia that became affected by permafrost during glacials (Fig. 2) (R. ZECH et al. 2010; ZECH et al. 2011). Apart from the obvious drawback, namely that more comparable outcrops should be studied to come up with robust estimates for permafrost carbon stock changes, one needs to keep in mind that thawing and landscape erosion during interglacials undoubtedly leads to soil carbon mineralization and destruction of much of the evidence for glacial-interglacial permafrost dynamics in many places. In that sense, the Tumara Paleosol Sequence might be special, because probably no major hiatus occurred, and the glacial sediments are still frozen and well-preserved today. In any case, the most accurate estimates for permafrost carbon stock changes on glacial-interglacial timescales will probably have to come from models. The only model estimate published so far for soil carbon released from the vast, non-glaciated Siberian permafrost regions during the last deglaciation ( 17-12 ka BP, before present) indicates that more than $1000 \mathrm{Pg} \mathrm{C}$ could have been released (ZImov et al. 2009). Modeling the complex physical and biogeochemi-

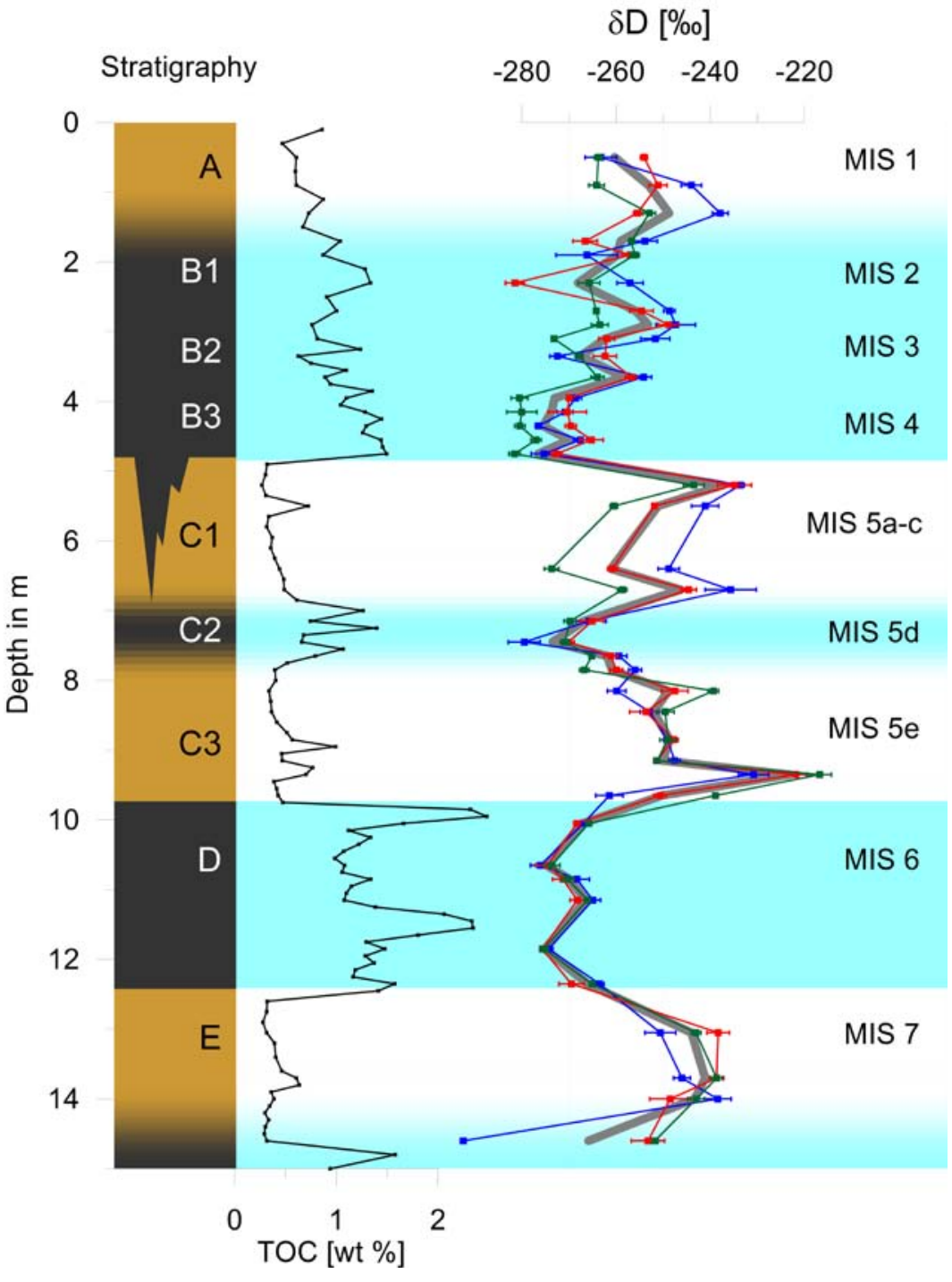

Fig. 1: Stratigraphy and analytical results for the loesspaleosol sequence 'Tumara'. The stratigraphy illustrates the alternation between organic-rich, dark grey units $B$ and $D$, and bright brown organic-poor units $A, C$ and $E . T O C=$ total organic carbon concentration. $\delta D=$ deuterium/hydrogen isotope ratios (blue: $n$-alkane C27, red: $n$-C29, green: $n$-C31, error bars: standard deviation of triplicate measurements, grey: average of all three alkanes). The tentative correlation with marine isotope stages (MIS) is shown to the right (modified from $R$. ZECH et al. 2010; ZECH et al. 2011).

$A b b$. 1: Stratigraphie und Analysenergebnisse für das Löss-Paleoboden-Profil „Tumara“. Die Stratigraphie illustriert die Abfolge der organikreichen, dunkelgrauen Horizonte $B$ und $D$, und der hellbraunen, organikarmen Horizonte $A, C$ und E. TOC = Bodenkohlenstoffkonzent ration. $\delta D=$ Deuterium/Wasserstoff Isotopenverhältnis (blau: $n$-Alkan C27, rot: n-C29, grün: n-C31, Fehlerbalken: Standardabweichung der Dreifachmessungen, grau: Mittelwert aller drei Alkane). Die Korrelation mit den Marinen Isotopen Stadien (MIS) ist rechts dargestellt (verändert nach R. ZECH et al. 2010; ZECH et al. 2011). 


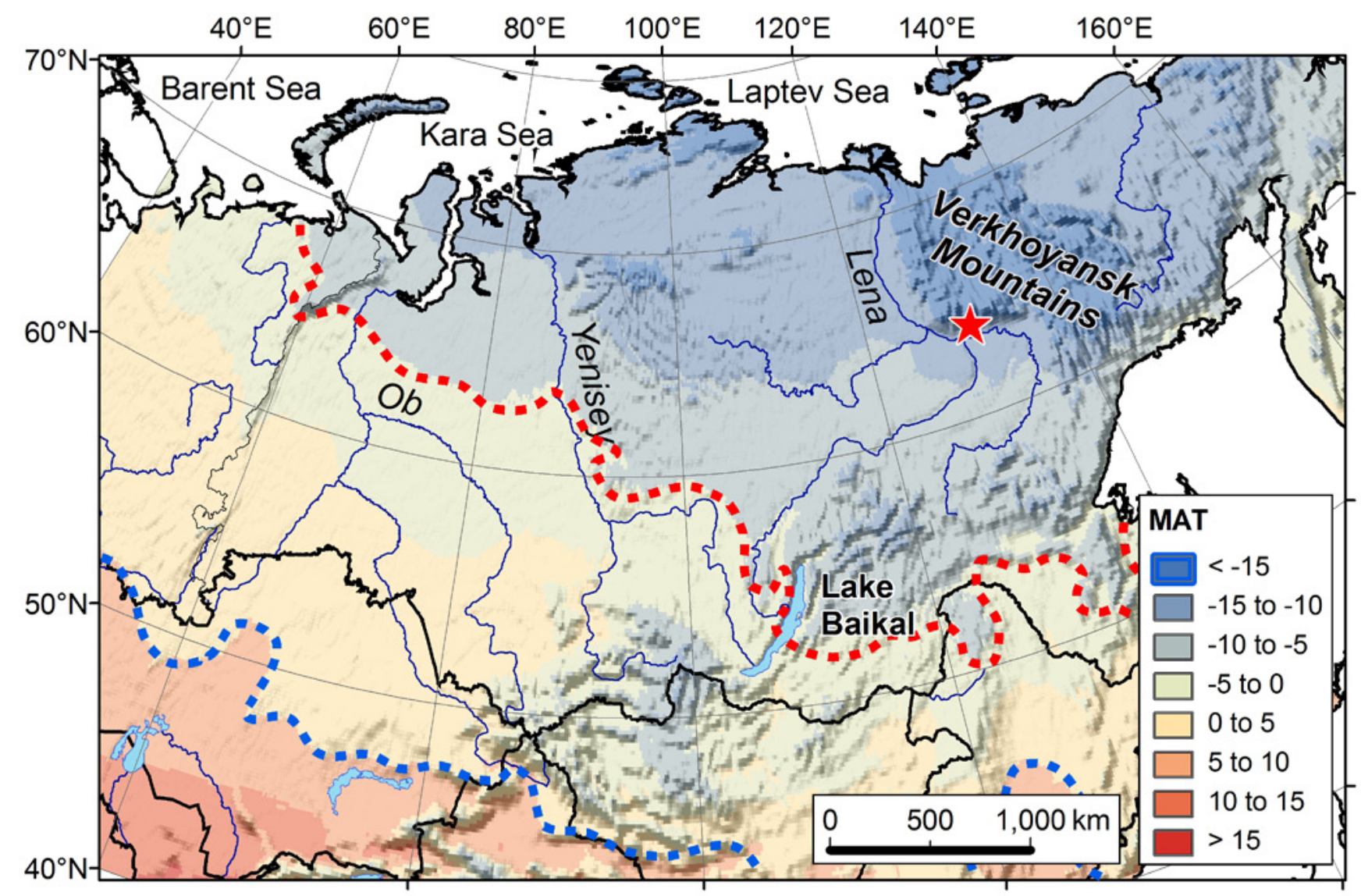

Fig. 2: Location of the Tumara Sequence (red star) and mean annual temperatures (MAT in ${ }^{\circ} \mathrm{C}$ ) in Siberia (NEW et al., 2002). The $-5^{\circ} \mathrm{C}$ isotherm (red dashed line) approximately marks the southward extent of continuous permafrost today (TARNOCAI et al. 2009). Discontinuous permafrost exists until MAT $0^{\circ} \mathrm{C}$, and the $+5^{\circ} \mathrm{C}$ isotherm (dashed blue line) indicates the approximate southward expansion of continuous permafrost during glacials assuming a $10^{\circ} \mathrm{C}$ temperature reduction (from R. ZECH et al. 2010; ZECH et al. 2011).

Abb. 2: Lage des Tumara Profils (roter Stern) und mittlere annuelle Temperaturen (MAT in ${ }^{\circ} \mathrm{C}$ ) in Sibirien (NEW et al. 2002). Die -5 ${ }^{\circ} \mathrm{C}$ Isotherme (rote, gestrichelte Linie) markiert ungefähr die heutige südliche Grenze des kontinuierlichen Permafrostes (TARNOCAI et al. 2009). Diskontinuierlichen Permafrost gibt es bis $M A T \sim 0^{\circ} \mathrm{C}$, und die $+5^{\circ} \mathrm{C}$ Isotherme (gestrichelte blaue Linie) markiert ungefähr die südliche Ausdehnung des kontinuierlichen Permafrostes während der Eiszeiten (unter Annahme einer $10^{\circ} \mathrm{C}$ Temperaturerniedrigung, nach R. ZECH et al. 2010; ZECH et al. 2011).

cal processes in permafrost soils is challenging, and future studies are necessary to evaluate this enormous figure.

Nonetheless, it is an interesting and worthwhile endeavor to pursue the potential consequences of assuming such large amounts of permafrost carbon being sequestered repeatedly in permafrost regions during each glacial. In the following, I will (i) briefly recap the state of knowledge concerning Pleistocene climate and the role of carbon dioxide, and then show that (ii) permafrost carbon might have contributed significantly to the observed glacial-interglacial changes in atmospheric $\mathrm{CO}_{2}$ concentrations without violating existing proxy evidence from carbon isotopes. (iii) I speculate that integrated annual insolation forcing of the permafrost carbon dynamics might have acted as trigger for global changes and (iv) suggest that the midPleistocene transition could be readily explained with the southern permafrost boundary reaching mid-latitudes during the course of the Pleistocene cooling trend.

\section{State of knowledge - 'burden' and 'helper' scenarios}

As we know from Antarctic ice cores, the $\sim 100$ ka rhythm of glacials and interglacials during the past $\sim 800 \mathrm{ka}$ was closely coupled to the global carbon cycle (LUETHI et al.
2008; Petit et al. 1999; Shackleton 2000). While low concentrations of atmospheric $\mathrm{CO}_{2}(\sim 180$ to $200 \mathrm{ppm})$ coincided with and most likely caused glacial periods, high concentrations ( 250 to $300 \mathrm{ppm})$ were characteristic for the interglacials. The prevailing notion to explain the glacialinterglacial changes in atmospheric $\mathrm{CO}_{2}$ concentrations is that the oceans were the principal driver and acted as net carbon sink during glacials (ARCHER et al. 2000; BROECKER 1982; Kohfeld \& Ridgwell 2010; Sigman \& Boyle 2000; Sigman, Hain \& Haug 2010). This shall here be referred to as 'ocean hypothesis'. Such a notion indeed appears unequivocal at first glance given the enormous size of the carbon pool in the ocean ( 60 times the atmospheric carbon). Particularly changes in the Southern Ocean circulation have recently been invoked to control atmospheric $\mathrm{CO}_{2}$, because up-welling of deep ocean water masses mainly occurs around Antarctica, where thus $\mathrm{CO}_{2}$ from remineralized marine organic material is vented back into the atmosphere (Fischer et al. 2010; Sigman, Hain \& HaUg 2010; Toggweiler, Russell \& CARson 2006).

Virtually all current glacial hypotheses and climate-carbon models, regardless of their favorite mechanisms and their specific model set-ups, not only build on the assumption that physical and/or biological changes in the ocean led 
to the sequestration of carbon dioxide in the deep glacial ocean, they also assume that the terrestrial carbon pools during glacials were smaller, and thus the ocean had to take up even more than just the $\sim 200 \mathrm{Pg} \mathrm{C}$ from the atmosphere ( 100 ppm change). Reduced carbon storage on land is in agreement with the intuitive view that net production of terrestrial biomass is lower during glacials, because lower temperatures, lower atmospheric $\mathrm{CO}_{2}$, and increased glacial aridity are less favorable conditions for plant growth. Quantitative estimates based on vegetation models indicate that the 'burden' may have been on the order of $\sim 600-$ 800 Pg C (François et al. 1998; Joos et al. 2004; KAPLAN et al. 2002), although much larger figures have been proposed as well (ADAMs \& FAURE 1998). Estimates of 300 to $700 \mathrm{Pg}$ $\mathrm{C}$ have been derived from $\sim 0.32 \%$ o more negative marine carbon isotopes (BIRD, LLYOD \& FARQUHAR 1996; DUPLESSY et al. 1988) that are commonly interpreted to document a net transfer of (isotopically negative) terrestrial carbon to the ocean.

There are, however, various reasons to doubt the currently widely accepted burden scenario:

1. Even when taking all possible physical and biological changes in the ocean into account, current carbon models are unable to convincingly explain the full range of glacial-interglacial changes in atmospheric $\mathrm{CO}_{2}\left(\mathrm{ARCH}^{-}\right.$ ER et al. 2000; Brovkin et al. 2007; FISCHER et al. 2010; Kohfeld \& Ridgwell 2010; Tagliabue et al. 2009).

2. The 'ocean hypothesis' suggests that a large pool of 'old' radiocarbon was trapped in the glacial deep ocean, yet there has been no success so far in finding this pool (Broecker \& Barker 2007; De Pol-Holz et al. 2010; SKINNER et al. 2010).

3. Models have not yet included permafrost carbon - a largely underestimated terrestrial carbon pool that was most likely even much larger during glacials.

It should be noted that earlier studies have already raised doubts concerning the burden scenario. ZENG (2003; 2007) has suggested that the assumed terrestrial burden might have been too large, because organic carbon buried below ice sheets has been ignored. Zeng also emphasized that a 'helper scenario', i.e. a net release of terrestrial carbon during terminations, would not be implausible. The recent estimates of huge amounts of carbon stored in permafrost soils, and particularly the potential release of more than $1000 \mathrm{Pg} C$ from thawing permafrost regions in Siberia during the last deglaciation (ZIMov et al. 2009) may now need to be considered in the overall balance as well and fuel the debate.

\section{Reconciling permafrost carbon dynamics with the global carbon cycle}

The uncertainties regarding the amount of 'excess' soil carbon storage in permafrost regions during glacials may be very large, but nonetheless it is certainly a justified endeavor to explore the potential consequences of large changes in permafrost carbon with regard to the global carbon cycle on glacial-interglacial timescales.

To begin with, if one took the $1000 \mathrm{Pg} \mathrm{C}$ released from thawing permafrost during terminations at face value as hitherto unrecognized additional terrestrial carbon pool change, this amount would massively affect the global climate. When considered in isolation of other terrestrial pools, most of the released permafrost carbon would be taken up by the ocean within a few millennia, and only about $10 \%$, i.e. $\sim 100 \mathrm{Pg} \mathrm{C}$, would remain in the atmosphere (Archer et al. 2004). Still, this would be equivalent to $\sim 50$ ppm atmospheric $\mathrm{CO}_{2}$ and thus be a significant contribution to the carbon balance on glacial-interglacial timescales.

A more balanced approach additionally has to consider that carbon released from thawing permafrost would partly be captured in other terrestrial carbon pools that increase during terminations, for example via plant and peat re-growth in formerly glaciated areas. Given the large uncertainties related to all involved carbon pools, it is probably impossible at this point to provide a robust calculation, but simply balancing the proposed $1000 \mathrm{Pg} \mathrm{C}$ permafrost carbon (Zimov et al. 2009) against estimates of $\sim 600$ to 800 $\mathrm{Pg} \mathrm{C}$ for terrestrial carbon based on vegetation models (excluding permafrost) (FrAnçOIs et al. 1998; Joos et al. 2004; KAPLAN et al. 2002) leaves a net release of $\sim 200$ to $400 \mathrm{Pg}$ $\mathrm{C}$ of terrestrial carbon into the atmosphere-ocean system during termination. Note that this balance is not including hundreds of Pg C that may have been buried below glacial ice sheets and also released during terminations (ZENG 2003; 2007), but that it also ignores the onset of peat formation after deglaciation, particularly in formerly glaciated areas of Siberia and North America (Jones \& YU 2010; MAcDonAlD et al. 2006). Nonetheless, our back-of-the-envelope calculation suggests that the 'burden' for the ocean may have been strongly overestimated, and that a 'helper' scenario may be realistic.

Would such a helper scenario be in contradiction with marine and ice core proxies?

\subsection{Carbon isotopic signals during deglaciation}

Negative carbon isotopic excursions of $\sim 0.5 \%$ o $\delta^{13} \mathrm{C}$ in ice core $\mathrm{CO}_{2}$ (LourAntou et al. 2010) and many ocean records (SPERo \& LEA 2002) during the termination, as well as the simultaneous $\sim 200 \%$ drop in atmospheric $\Delta^{14} \mathrm{C}$ (BROECKER \& BARKER 2007; HugheN et al. 2006) have generally been interpreted as evidence for the release of (isotopically depleted and old) carbon that was trapped in the deep ocean during glacials. Apart from the fact that this supposedly trapped large deep ocean carbon pool has not been found so far (Broecker \& BARKer 2007; De Pol-Holz et al. 2010; SKINNER et al. 2010), one should keep in mind that the isotopic signature of this pool would be very similar to permafrost carbon (Brovkin et al. 2002). It may thus be worth pursuing the idea of massive permafrost carbon release during terminations instead of, or at least in combination with deep ocean carbon.

Back-of-the-envelope calculations could be based on a net-release of 200 to $400 \mathrm{Pg} \mathrm{C}$ permafrost carbon ( $-27 \%$ o $\delta^{13} \mathrm{C}$ and radiocarbon dead, i.e. $\left.-1000 \% \circ \Delta^{14} \mathrm{C}\right)$ into the glacial atmosphere $\left(\sim 400 \mathrm{Pg} \mathrm{C}, \sim-7 \% \circ \delta^{13} \mathrm{C}\right.$ and $\left.\sim 400 \% \circ \Delta^{14} \mathrm{C}\right)$. As the ocean will take up $\sim 90 \%$ of the released permafrost carbon on millennial timescales, the mass balance needs to be made with the remaining $10 \%$, i.e. $\sim 20$ to $40 \mathrm{Pg} \mathrm{C}$. This yields 
a $\sim 1$ to $2 \%$ drop in atmospheric (and upper ocean) $\delta^{13} \mathrm{C}$ and a $\sim 70$ to $140 \%$ o drop $\Delta{ }^{14} \mathrm{C}$, which is in reasonable agreement with the observations. More sophisticated calculations and modeling studies, similar to the one by KoEHLER et al. (2006), would of course be promising to refine those numbers and put better constraints on the permafrost carbon pool changes.

\subsection{Carbon isotopic signals during the LGM}

The $\sim 0.32 \%$ o more negative mean ocean $\delta^{13} \mathrm{C}$ during the last glacial has traditionally been suggested to reflect a net carbon transfer of 300 to $700 \mathrm{Pg} \mathrm{C}$ from the terrestrial biosphere to the ocean (BIRD, LlYod \& FARQUHAR 1996; DuPlessy et al. 1988). The hypothetical helper scenario above, however, would imply a net terrestrial carbon storage of 200 to $400 \mathrm{Pg}$ during glacials, which would leave the ocean (and atmosphere) more enriched by $\sim 0.2-0.4 \%$. Two considerations might help to reconcile these apparent discrepancies.

First, the widely used value of $-0.32 \%$ was derived from a relatively limited set of ocean sediment cores, and although a more recent synthesis undoubtedly corroborates more negative values in the deep ocean during glacials, it also shows that large differences exist between individual records, and that the signal is much less clear in intermediate and surface ocean waters (OlIVER et al. 2010). Above $\sim 2000 \mathrm{~m}$ water depth, the oceans may have been more $\delta^{13} \mathrm{C}$ positive during glacials (see also CURry \& Oppo 2005; MAтsumoto et al. 2002). An independent piece of evidence for more positive surface waters might in fact come from the ice core $\delta^{13} \mathrm{CO}_{2}$. The LGM and Holocene $\delta^{13} \mathrm{CO}_{2}$ values are almost identical, although the isotopic fractionation between the surface ocean and the atmosphere changed by $\sim 0.5 \%$ o due to lower temperatures and increased salinity (KöHLER, FIScher ひ SChmitT 2010; Lourantou et al. 2010). Whereas KoeHLer et al. (2010) invoke sea ice, iron fertilization and ocean circulation effects (which are all highly uncertain, see e.g. KoHfELD \& RIDGwell 2010) to offset the temperature and salinity effect, it might also be possible to reconcile the ice core $\delta^{13} \mathrm{CO}_{2}$ observations with more $\delta^{13} \mathrm{C}$ positive surface ocean waters and a helper rather than a burden scenario (see also TAgLiabue et al. 2009).

Second, and more importantly, it is not trivial to infer past isotopic changes in dissolved inorganic carbon from $\delta^{13} \mathrm{C}$ measured in foraminifera, because many other factors, such as ocean chemistry, ocean circulation and vital effects, need to be considered (e.g. Oliver et al. 2010). Culture experiments, for example, indicate that the glacial rise in surface ocean carbonate ion concentrations can account for at least a $0.25-0.5 \%$ drop in shell $\delta^{13} \mathrm{C}$ (SPERO et al. 1997). LEA et al. (1999) further elaborate on this issue and predict anomalies in shell $\delta^{13} \mathrm{C}$ between -0.3 and $-0.9 \%$. Both studies acknowledge that similar corrections may not be valid for the deep ocean isotope records, but one could argue that changes in the biological pump, deep ocean chemistry, and ocean circulation leave plenty of possible explanations for a negative bias of the deep ocean $\delta^{13} \mathrm{C}$ record.

In summary, a significant permafrost carbon contribution to the glacial-interglacial carbon balance is not necessarily contradicting existing carbon isotope proxies and might in fact help reconciling many observations.

\section{Integrated annual insolation as external forcing for permafrost and trigger for global climate change}

In the following, we shall hypothetically assume that the permafrost carbon contributions are large enough to dominate the net terrestrial carbon fluxes and to affect atmospheric $\mathrm{CO}_{2}$. This specific helper scenario could be coined 'permafrost scenario'. To provide again a rough quantitative estimate, the net terrestrial carbon of $\sim 200$ to $400 \mathrm{Pg}$ $\mathrm{C}$ released during the last termination (from the above back-of-the-envelope calculation) would be equivalent to $\sim 100$ to $200 \mathrm{ppm}$ atmospheric $\mathrm{CO}_{2}$. Particularly in view of the fact that part of the permafrost carbon is released as methane and thus as efficient greenhouse gas, these large numbers suggest that permafrost carbon dynamics could be sufficient to trigger global climate changes. One needs to keep in mind, of course, that $\sim 90 \%$ of the emitted carbon will be taken up by the ocean within a few millennia. Thus, other mechanisms, such as previously suggested physical and biological changes in the ocean, ultimately still need to explain most of the $\sim 100$ ppm glacial-interglacial changes in atmospheric $\mathrm{CO}_{2}$. In that sense, permafrost carbon dynamics should be considered only a hitherto unrecognized, additional mechanism. Importantly, however, permafrost carbon dynamics may not only be a positive feedback, but also act as trigger for climate change, with many of the other mechanisms acting as amplifiers.

But what in turn could be the forcing for permafrost carbon dynamics? One can argue that permafrost carbon dynamics are most sensitive to changes of the southern permafrost boundary, because the existence of permafrost exerts an important control on the drainage of soil water and thus soil organic matter preservation, whereas the depth of the active layer in permafrost regions is of secondary importance. And as mean annual temperatures determine the existence of permafrost, the search for the external forcing leads us to the mean or integrated annual insolation at the southern permafrost boundary.

At high latitudes $\left(>45^{\circ} \mathrm{N}\right)$, integrated annual insolation is mainly controlled by the orbital parameter obliquity (Huybers 2006) (Fig. 3). Decreasing/low obliquity can accordingly be expected to favor the expansion of permafrost and enhanced carbon sequestration every $\sim 41 \mathrm{ka}$. Increasing/high obliquity, on the other hand, favors permafrost thawing and soil carbon mineralization. This forcing could readily explain the ice-age rhythm in the ' 41 ka world' during the early Pleistocene ( 1-2 Ma), which was characterized by $\sim 41$ ka glacial-interglacial cycles (HuyBERs 2006; Raymo \& Nisancioglu 2003) (Fig. 4).

\section{The mid-Pleistocene transition}

But what could have caused the mid-Pleistocene transition, i.e. the transition from the ' 41 ka world' to longer, approximately 100 ka glacial cycles (CLARK, Alley \& POLLARD 1999; Huybers 2006; Raymo \& Nisancioglu 2003; Tziperman \& Gildor 2003) (Fig. 4)? After the explanation of the glacialinterglacial changes in atmospheric $\mathrm{CO}_{2}$, this is in fact the second 'holy grail' in Quaternary paleoclimatology. It has recently been recognized that the $\sim 100$ ka glacial cycles are probably $\sim 80$ or $\sim 120$ ka cycles and thus related to the orbit- 


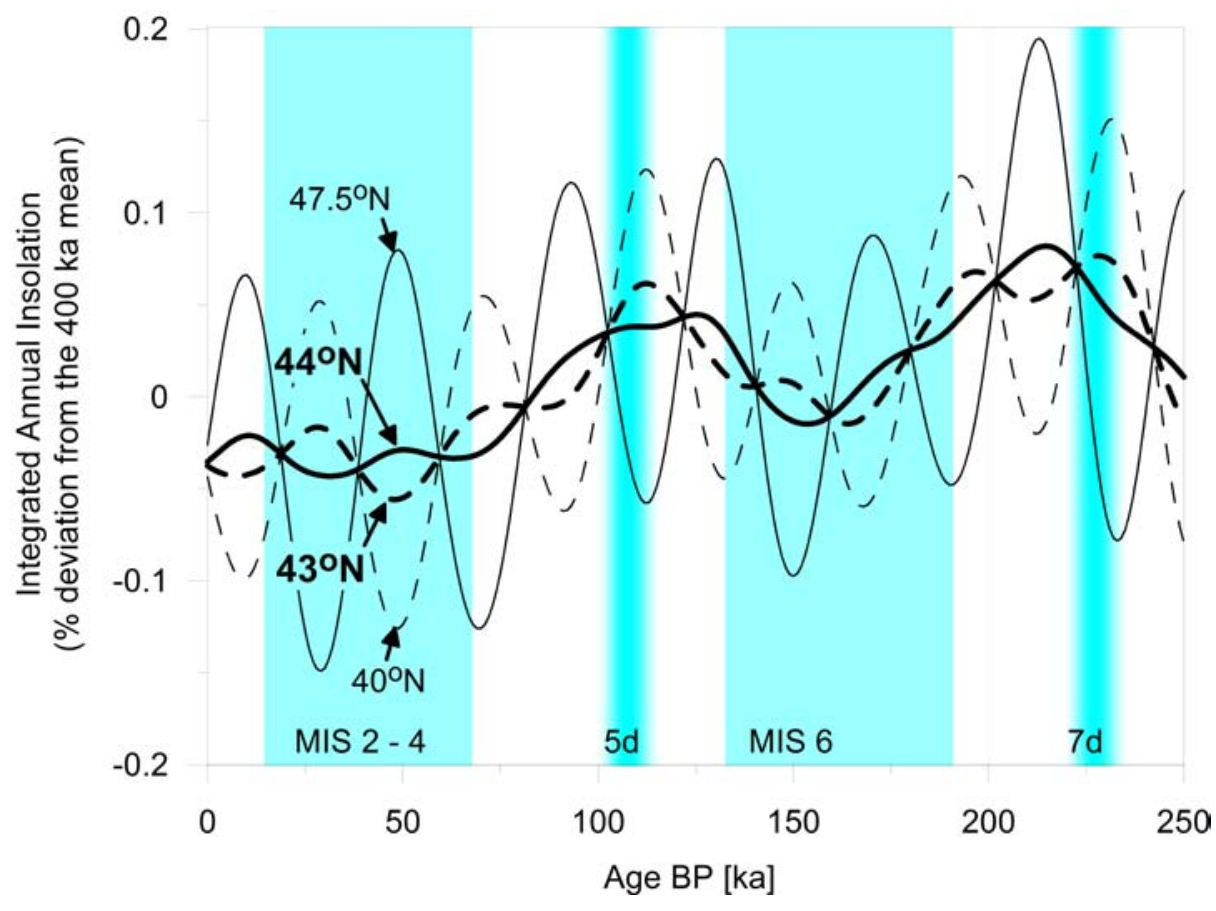

Fig. 3: Integrated annual insolation for 47.5, 44, 43 and $40^{\circ} \mathrm{N}$ (BERGER \& LOUTRE 1991). The $400 \mathrm{ka}$ means are $9.4,9.9$, 10.0, and $10.4 \mathrm{GJ} / \mathrm{m}^{2}$.

Abb. 3: Integrierte annuelle Insolation für 47.5, 44, 43 und $40^{\circ} \mathrm{N}$ (BERGER \& LOUTRE 1991). Die $400 \mathrm{ka}$ Mittelwerte sind 9.4, 9.9, 10.0, und $10.4 \mathrm{GJ} / \mathrm{m}^{2}$. al parameter obliquity rather than eccentricity (HUYBERS 2007), yet adequate and convincing explanations for the 'skipped obliquity cycles' remain elusive. In the following, I outline how the permafrost glacial hypothesis provides an intriguingly simple and elegant concept that could explain the transition.

As long as the southern permafrost boundary is north of $\sim 45^{\circ} \mathrm{N}$, the insolation forcing of permafrost carbon dynamics is directly and only controlled by obliquity (Fig. 3). While this was probably the case before the transition and could explain the $41 \mathrm{ka}$ world, the overall long-term cooling trend during the Pleistocene must have reached a threshold, when expansion of permafrost areas during glacials reached latitudes south of $\sim 45^{\circ} \mathrm{N}$. Note that today, continuous permafrost regions in Siberia already extend to $\sim 55^{\circ} \mathrm{N}$ (TARNOCAI et al. 2009) (Fig. 2), and that during the last glacial, permafrost regions undoubtedly extended southward beyond $45^{\circ} \mathrm{N}$. Integrated annual insolation south of $\sim 45^{\circ} \mathrm{N}$ shows the opposite signal compared to north of $\sim 45^{\circ} \mathrm{N}$, because obliquity (the tilt of the Earth' axis) basically controls the amount of insolation that reaches high latitudes rather than the equator. The exact latitude where the sign of the obliquity forcing flips may in fact be between 43 and $44^{\circ} \mathrm{N}$ (Fig. 3), but the crux is that once the Pleistocene cooling was sufficient for glacial permafrost areas to reach mid-latitudes, the southern permafrost boundary and the related carbon dynamics became insensitive (or at least less sensitive) to changes in obliquity. The external forcing that remains is then eccentricity. I suggest that as a consequence, obliquity cycles (glacial terminations) were skipped during the Middle and Late Pleistocene, when they coincided with decreasing annual insolation at mid-latitudes due to eccentricity. Only the next obliquity maximum that coincided with increasing eccentricity kicked off the warming feedbacks related to thawing permafrost and $\mathrm{CO}_{2}$ and methane releases. The result are glacial terminations every $\sim 80$ or 120 ka during the Late Pleistocene, i.e. exactly the observed succession of the ice ages (Huybers 2007) (Fig. 4).

\section{Conclusions}

Recent studies have shown that the amount of soil organic carbon in permafrost regions has been greatly underestimated today, and very likely even more so during past glacials. Permafrost plays a very important role for the hydrological conditions in soils, and thus also for changes in mineralization versus preservation of organic material. This leads to the formulation of a permafrost glacial hypothesis:

(i) The amount of soil organic carbon released from thawing permafrost during glacial terminations at least partly compensated the carbon sequestered by expanding biomass, facilitating the explanation of glacial-interglacial changes in atmospheric $\mathrm{CO}_{2}$ concentrations.

(ii) Carbon isotopic records derived from marine sediments and ice cores might be more easily reconciled when taking permafrost carbon dynamics into account. In any case, they do not necessarily contradict a net release of terrestrial carbon during terminations. Thus the 'terrestrial burden' may not only have been overestimated, the possibility of a 'helper scenario' should also not be ruled out.

(iii) Integrated annual insolation forcing, which likely affects permafrost carbon dynamics most effectively at the southern permafrost boundary, provides an external forcing for permafrost carbon dynamics on orbital timescales.

(iv) The long Pleistocene cooling trend implies the expansion of permafrost regions to mid-latitudes at some point in the past. If this occurred during the mid-Pleistocene transition, it could automatically explain the transition from obliquity forcing (dominant north of $\sim 45^{\circ} \mathrm{N}$ ) to longer $\sim 80$ or 120 ka ice age cycles, because permafrost carbon dynamics at mid-latitudes are dominantly forced by eccentricity. 


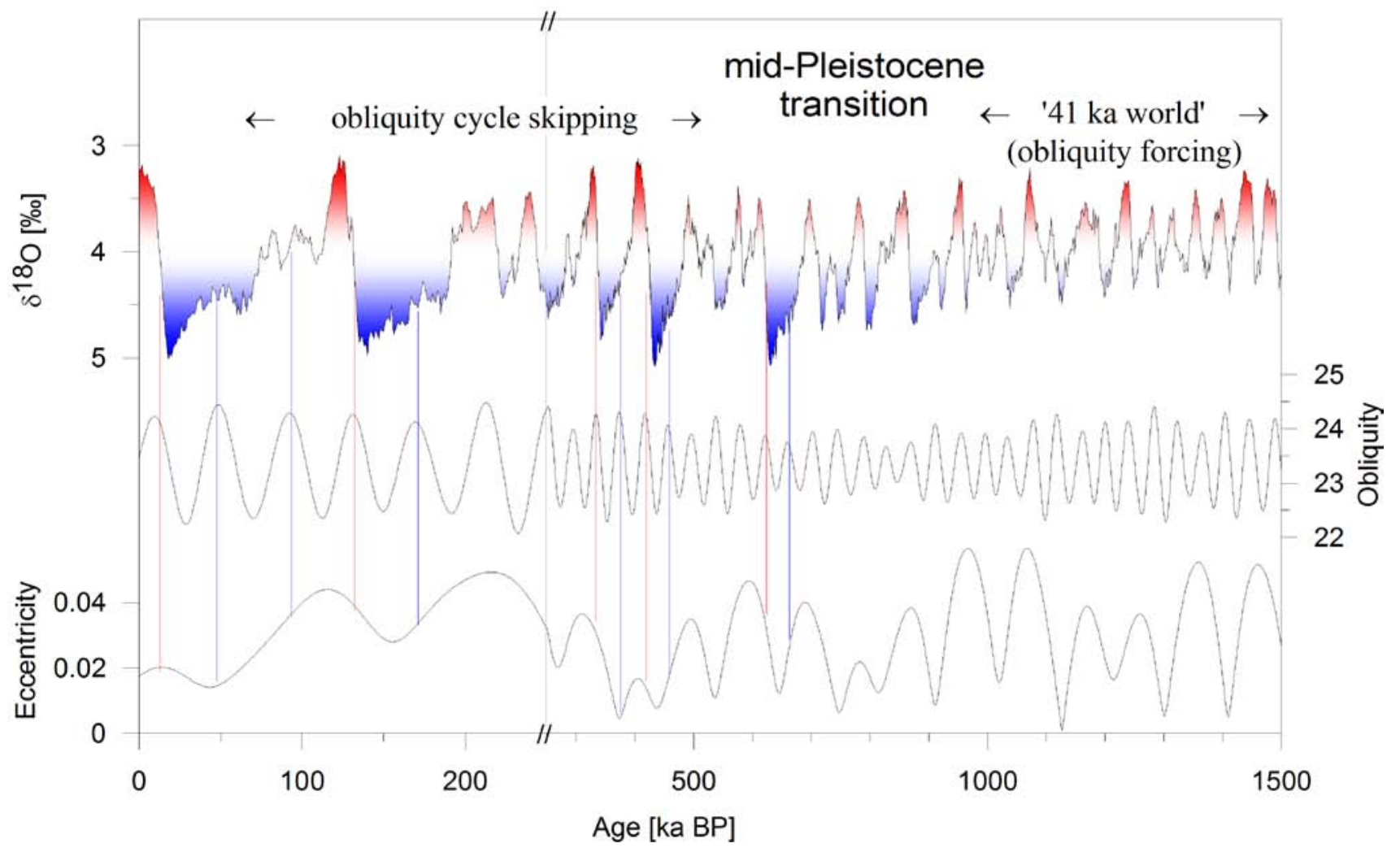

Fig. 4: Outline of the permafrost glacial hypothesis explaining the obliquity cycle skipping after the mid-Pleistocene transition. The marine $\delta^{18} \mathrm{O}$ stack illustrates changes in global ice volume and global temperatures (LISIECKI \& RAYMO 2005), obliquity and eccentricity the relevant orbital forcing parameters (BERGER \& LOUTRE 1991). Blue lines mark prominent examples where obliquity cycles were skipped. Red lines mark subsequent obliquity maxima that coincided with increasing eccentricity and that therefore triggered major terminations.

Abb. 4: Darstellung der pleistozänen Eiszeitenabfolge und deren potentielle Erklärung mit Hilfe der Permafrost Hypothese. Die marine $\delta^{18} O$ Kurve illustriert die Änderungen des globalen Eisvolumens und der globalen Temperaturen (LISIECKI \& RAYMO 2005), die Schiefe der Ekliptik und die Ekzentrizität, die relevanten orbitalen Insolationsparameter (BERGER \& LOUTRE 1991). Blaue Linien markieren exemplarisch Fälle, in denen ein 41 ka Zyklus ausfiel. Rote Linien markieren nachfolgende Maxima in der Schiefe der Ekliptik, welche mit steigender Ekzentrizität einhergingen und damit das Ende einer Eiszeit einleiteten.

Although the permafrost glacial hypothesis may seem to challenge much of the current knowledge and existing hypotheses at first glance (particularly the paradigm that the glacial ocean acted as net sink for $\mathrm{CO}_{2}$ ), many marine proxies and findings from global carbon models might in fact be reconciled more easily when permafrost is taken into account.

Two approaches seem to be most appropriate to evaluate the permafrost glacial hypothesis. The first one could be to further investigate the potential carbonate ion or $\mathrm{pH}$ effect on shell $\mathrm{d}^{13} \mathrm{C}$ in benthic foraminifera, in order to come up with new estimates for mean ocean $\mathrm{d}^{13} \mathrm{C}$ changes and thus net terrestrial carbon budgets on glacial-interglacial timescales. The second approach could be to develop more sophisticated soil carbon - climate models that explicitly include permafrost dynamics and peatland growth, in order to obtain more robust estimates of the amount of organic carbon stored at high latitudes during glacials. I hope this manuscript inspires respective research in the near future.

\section{Acknowledgements}

I thank M. Zech, Y. Huang, J. Russell, T. Eglinton, N. Gruber and J. Zech for discussions. Support through a SNF PostDoc fellowship is gratefully acknowledged.

\section{References}

AdAms, J.M. \& FAure, H. (1998): A new estimate of changing carbon storage on land since the last glacial maximum, based on global land ecosystem reconstruction. - Global and Planetary Change, 16: 3-24.

Archer, D., Winguth, A., LeA, D. \& Mahowald, N. (2000): What caused the glacial/interglacial atmospheric $\mathrm{pCO}_{2}$ cycles? - Review of Geophysics, 38: 159-189.

Archer, D., Martin, P., Buffett, B., Brovkin, V., Rahmstorf, S. \& GANOPOLSKI, A. (2004): The importance of ocean temperature to global biogeochemistry. - Earth and Planetary Science Letters, 222: 333-348.

Berger, A. \& Loutre, M.F. (1991): Insolation values for the climate of the last 10 million of years. - Quaternary Sciences Review, 10: 297-317.

Bird, M.I., Llyod, J. \& FARQUHAR, G.D. (1996): Terrestrial carbon-storage from the last glacial maximum to the present. - Chemosphere, 33: $1675-1685$.

Bond-Lamberty, B. \& Thomson, A. (2010): Temperature-associated increases in the global soil respiration record. - Nature, 464: 579-582.

Broecker, W. (1982): Glacial to interglacial changes in ocean chemistry. Progress in Oceanography, 2: 151-197.

Broecker, W. \& BARKer, S. (2007): A 190\%o drop in atmosphere's $\Delta^{14} \mathrm{C}$ during the "Mystery Interval" (17.5 to $14.5 \mathrm{kyr}$ ). - Earth and Planetary Science Letters, 256: 90-99.

Brovkin, V., Hofmann, M., Bendtsen, J. \& Ganopolski, A. (2002): Ocean biology could control atmospheric $\delta^{13} \mathrm{C}$ during glacial-interglacial cycle. - Geochemistry, Geophysics, Geosystems, 3.

Brovkin, V., Ganopolski, A., Archer, D. \& Rahmstorf, S. (2007): Lowering glacial atmospheric $\mathrm{CO}_{2}$ in response to changes in oceanic circulation and marine biogeochemistry. - Paleoceanography, 22: 1-14. 
Clark, P.U., Alley, R.B. \& Pollard, D. (1999): Northern Hemisphere Ice Sheet Influences on Global Climate Change. - Science, 286: 1104-1111.

Curry, W.B. \& Oppo, D.W. (2005): Glacial water mass geometry and the distribution of $\delta^{13} \mathrm{C}$ of $\Sigma \mathrm{CO}_{2}$ in the western Atlantic Ocean. - Paleoceanography, 20: PA1017. Doi:10.1029/2004PA001021.

DAvidson, E.A. \& JANSSENS, I.A. (2006): Temperature sensitivity of soil carbon decomposition and feedbacks to climate change. - Nature, 440: 165-173.

De Pol-Holz, R., Keigwin, L., Southon, J., Hebbeln, D. \& Mohtadi, M. (2010): No signature of abyssal carbon in intermediate waters off Chile during deglaciation. - Nature Geoscience, 3: 192-195.

Duplessy, J.C., Shackleton, N.J., Fairbanks, R.G., Labeyrie, L., Oppo, D. \& KAlLEL, N. (1988): Deepwater Source Variations During the Las Climatic Cycle and Their Impact on the Global Deepwater Circulation. - Paleoceanography, 3: 343-360.

Fischer, H., Schmitt, J., Lüthi, D., Stocker, T.F., Tschumi, T., PARekh, P. Joos, F. et al. (2010): The role of Southern Ocean processes in orbital and millennial $\mathrm{CO}_{2}$ variations - A synthesis. - Quaternary Science Reviews, 29: 193-205.

François, L.M., Delire, C., Warnant, P. \& Munhoven, G. (1998): Modelling the glacial-interglacial changes in the continental biosphere. Global and Planetary Change, 16: 37-52.

Gruber, N., Friedlingstein, P., Field, C.B., Valentini, R., Heimann, M., Richey, J.E., Romero-LANkao, P. et al. (2004): The vulnerability of the carbon cycle in the 21st century: An assessment of carbon-climatehuman interactions. - In: Field, C. B. \& RAupach, M. R. (eds.): Toward $\mathrm{CO}_{2}$ Stabilization: Issues, Strategies, and Consequences: 45-76 Washington, D.C. (Island Press).

Hughen, K., Southon, J., Lehman, S., Bertrand, C. \& Turnbull, J. (2006): Marine-derived ${ }^{14} \mathrm{C}$ calibration and activity record for the past 50,000 years updated from the Cariaco Basin. - Quaternary Science Reviews, 25: 3216-3227.

Huybers, P. (2006): Early Pleistocene Glacial Cycles and the Integrated Summer Insolation Forcing. - Science, 313: 508-511.

Huybers, P. (2007): Glacial variability over the last two million years: an extended depth-derived age model, continuous obliquity pacing, and the Pleistocene progression. - Quaternary Science Reviews, 26: 37-55.

Jones, M.C. \& YU, Z. (2010): Rapid deglacial and early Holocene expansion of peatlands in Alaska. - Proceedings of the National Academy of Sciences, 107: 7347-7352.

Joos, F., Gerber, S., Prentice, I.C., Otto-Bliesner, B.L. \& Valdes, P.J (2004): Transient simulations of Holocene atmospheric carbon dioxide and terrestrial carbon since the Last Glacial Maximum. - Global Biogeochemical Cycles, 18: GB2002. Doi:10.1029/2003GB002156.

Kaplan, J.O., Prentice, I.C., Knorr, W. \& Valdes, P.J. (2002): Modeling the dynamics of terrestrial carbon storage since the Last Glacial Maximum. - Geophysical Research Letters, 29. Doi:10.1029/2002GL015230.

Khvorostyanov, D.V., Ciais, P., Krinner, G. \& Zimov, S.A. (2008): Vulnerability of east Siberia's frozen carbon stores to future warming. Geophysical Research Letters, 35. Doi:10.1029/2008GL033639.

Kohfeld, K.E. \& Ridgwell, A.J. (2010): Glacial-interglacial variability in atmospheric $\mathrm{CO}_{2}$. - In: Saltzman, E. \& Quere, C. L. (eds.): Surface ocean - lower atmospheres processes. - Geophysical Monograph Series: 251-286; Washington D.C. (AGU)

Köhler, P., Fischer, H. \& Schmitt, J. (2010): Atmospheric $\delta^{13} \mathrm{CO}_{2}$ and its relation to $\mathrm{pCO}_{2}$ and deep ocean $\delta^{13} \mathrm{C}$ during the late Pleistocene. Paleoceanography, 25: PA1213. Doi:10.1029/2008PA001703.

Köhler, P., Fischer, H., Schmitt, J. \& Munhoven, G. (2006): On the application and interpretation of Keeling plots in paleo climate research - deciphering $\delta^{13} \mathrm{C}$ of atmospheric $\mathrm{CO}_{2}$ measured in ice cores. - Biogeosciences, 3: 539-556

Lea, D.W., Bijma, J., Spero, H.J. \& Archer, D. (1999): Implications of a carbonate ion effect on shell carbon and oxygen isotopes for glacial ocean conditions. - In: Fischer, G. \& Wefer, G. (eds.): Use of Proxies in Paleoceanography: Examples from the South Atlantic: 513-522; Berlin, Heidelberg (Springer)

Lisiecki, L.E. \& RAYMO, M.E. (2005): A Pliocene-Pleistocene stack of 57 globally distributed benthic $\delta^{18} \mathrm{O}$ records. - Paleoceanography, 20 PA1003. Doi:10.1029/2004PA001071.

Lourantou, A., Lavric, J., Köhler, P., Barnola, J.-M., Paillard, D. Michel, E., Raynaud, D. et al. (2010): Constraint of the $\mathrm{CO}_{2}$ rise by new atmospheric carbon isotopic measurements during the last deglaciation. - Global Biogeochemical Cycles, 24: GB2015. Doi:10.1029/2009GB003545.

Luethi, D., Le Floch, M., Bereiter, B., Blunier, T., Barnola, J.-M., SieGENTHAler, U., RAynAud, D. et al. (2008): High-resolution carbon di- oxide concentration record $650,000-800,000$ years before present. Nature, 453: 379-382.

MacDonald, G.M., Beilman, D.W., Kremenetski, K.V., Sheng, Y., Smith, L.C. \& Velichro, A.A. (2006): Rapid Early Development of Circumarctic Peatlands and Atmospheric $\mathrm{CH}_{4}$ and $\mathrm{CO}_{2}$ Variations. - Science, 314: 285-288.

Matsumoto, K., OвA, T., Lynch-Stieglitz, J. \& Yamamoto, H. (2002) Interior hydrography and circulation of the glacial Pacific Ocean. Ouaternary Science Reviews, 21: 1693-1704.

Muhs, D.R., Ager, T.A., Bettis Ill, E.A., McGeehin, J., Been, J.M., Beget, J.E., PAVICH, M.J. et al. (2003): Stratigraphy and palaeoclimatic significance of Late Quaternary loess-palaeosol sequences of the Last Interglacial-Glacial cycle in central Alaska. - Quaternary Science Reviews, 22: 1947-1986.

New, M., Lister, D., Hulme, M. \& MAKin, I. (2002): A high-resolution data set of surface climate over global land areas. - Climate Research, 21: $1-25$.

Oliver, K.I.C., Hoogakker, B.A.A., Crowhurst, S., Henderson, G.M., Rickaby, R.E.M., Edwards, N.R. \& Elderfield, H. (2010): A synthesis of marine sediment core $\delta^{13} \mathrm{C}$ data over the last 150000 years. - Climate of the Past, 6: 645-673.

Petit, J.R., Jouzel, J., Raynaud, D., Barkov, N.I., Barnola, J.-M., Basile, I., BENDER, M. et al. (1999): Climate and atmospheric history of the past 420,000 years from the Vostok ice core, Antarctica. - Nature, 399: 429-436.

Raymo, M.E. \& NisAncioglu, K. (2003): The 41 kyr world: Milankovitch's other unsolved mystery. - Paleoceanography, 18. Doi:10.1029/2002PA000791

Reyes, A.V., Froese, D.G. \& Jensen, B.J.L. (2010): Permafrost response to last interglacial warming: field evidence from non-glaciated Yukon and Alaska. - Quaternary Science Reviews, 29: 3256-3274.

Schaefer, K., Zhang, T., Bruhwiler, L. \& Barrett, A.P. (2011): Amount and timing of permafrost carbon release in response to climate warming. - Tellus, 63B: 165-180.

Schirrmeister, L., Siegert, C., Kunitzky, V., Grootes, P. \& Erlenkeuser, H. (2002): Late Quaternary ice-rich permafrost sequences as a paleoenvironmental archive for the Laptev Sea Region in northern Siberia. - International Journal of Earth Sciences, 91: 154-167.

Schuur, E.A.G., Bockheim, J., Canadell, J.G., Euskirchen, E., Field, C.B., Goryachinin, S.V., Hagemann, S. et al. (2008): Vulnerability of Permafrost Carbon to Climate Change: Implications for the Global Carbon Cycle. - Bioscience, 58: 701-714.

Shackleton, N.J. (2000): The 100,000-Year Ice-Age Cycle Identified and Found to Lag Temperature, Carbon Dioxide, and Orbital Eccentricity. - Science, 289: 1897-1902.

Sigman, D.M. \& Boyle, E.A. (2000): Glacial/interglacial variations in atmospheric carbon dioxide. - Nature, 407: 859-869.

Sigman, D.M., Hain, M.P. \& Haug, G.H. (2010): The polar ocean and glacial cycles in atmospheric $\mathrm{CO}_{2}$ concentration. - Nature, 466: 47-55.

Skinner, L.C., Fallon, S., Waelbroeck, C., Michel, E. \& Barker, S. (2010): Ventilation of the Deep Southern Ocean and Deglacial $\mathrm{CO}_{2}$ Rise. - Science, 328: 1147-1151.

Spero, H.J. \& LEA, D.W. (2002): The Cause of Carbon Isotope Minimum Events on Glacial Terminations. - Science, 296: 522-525.

Spero, H.J., Bijma, J., Lea, D.W. \& Bemis, B.E. (1997): Effect of seawater carbonate concentration on foraminiferal carbon and oxygen isotopes. - Nature, 390: 497-500.

Tagliabue, A., Bopp, L., Roche, D.M., Bouttes, N., Dutay, J.-C., Alkama, R., KageyamA, M. et al. (2009): Quantifying the roles of ocean circulation and biogeochemistry in governing ocean carbon-13 and atmospheric carbon dioxide at the last glacial maximum. - Climate of the Past, 5: 695-706.

Tarnocai, C., Canadell, J.G., Schuur, E.A.G., Kuhry, P., Mazhitova, G. \& Zimov, S. (2009): Soil organic carbon pools in the northern circumpolar permafrost region. - Global Biogeochemical Cycles, 23: GB2023. Doi:10.1029/2008GB003327.

Toggweiler, J.R., Russell, J.L. \& CARson, S.R. (2006): Midlatitude wester lies, atmospheric $\mathrm{CO} 2$, and climate change during the ice ages. - Paleoceanography, 41. Doi:10.1029/2005PA001154.

Tziperman, E. \& GILDOR, H. (2003): On the mid-Pleistocene transition to 100-kyr glacial cycles and the asymmetry between glaciation and deglaciation times. - Paleoceanography, 18. Doi:10.1029/2001PA000627.

Wetterich, S., Kuzmina, S., Andreev, A.A., Kienast, F., Meyer, H., Schirrmeister, L., Kuznetsova, T. et al. (2008): Palaeoenvironmental dynamics inferred from late Quaternary permafrost deposits on $\mathrm{Ku}$ rungnakh Island, Lena Delta, Northeast Siberia, Russia. - Quaternary Science Reviews, 27: 1523-1540. 
Zech, M., Zech, R. \& Glaser, B. (2007): A 240,000-year stable carbon and nitrogen isotope record from a loess-like palaeosol sequence in the Tumara Valley, Northeast Siberia. - Chemical Geology, 242: 307-318.

Zech, M., Zech, R., Zech, W., Glaser, B., Brodowski, S. \& Amelung, W. (2008): Characterisation and palaeoclimate of a loess-like permafrost palaeosol sequence in NE Siberia. - Geoderma, 143: 281-295.

Zech, M., Andreev, A., Zech, R., Mueller, S., Hambach, U., Frechen, M. \& ZECH, W. (2010): Quaternary vegetation changes derived from a loess-like permafrost palaeosol sequence in northeast Siberia using alkane biomarker and pollen analyses. - Boreas, 39: 540-550.

Zech, R., Huang, Y., Zech, M., Tarozo, R. \& Zech, W. (2010): A permafrost glacial hypothesis to explain atmospheric $\mathrm{CO}_{2}$ and the ice ages during the Pleistocene. - Climate of the Past Discussions, 6: 2199-2221.

Zech, R., Huang, Y., Zech, M., Tarozo, R. \& Zech, W. (2011): High carbon sequestration in Siberian permafrost loess-paleosols during glacials. - Climate of the Past, 7: 501-509.

ZENG, N. (2003): Glacial-interglacial atmospheric $\mathrm{CO}_{2}$ changes - the Glacial Burial Hypothesis. - Advances in Atmospheric Sciences, 20: 677-693.

ZENG, N. (2007): Quasi-100 ky glacial-interglacial cycles triggered by subglacial burial carbon release. - Climate of the Past, 3: 135-153.

Zimov, N.S., Zimov, S.A., Zimova, A.E., Zimova, G.M., Chuprynin, V.I. \& CHAPIN, F.S., III (2009): Carbon storage in permafrost and soils of the mammoth tundra-steppe biome: Role in the global carbon budget. Geophysical Research Letters, 36: L02502. Doi:10.1029/2008GL036332.

Zimov, S.A., SchuUr, E. \& ChApIN III, F.S. (2006): Permafrost and the Global Carbon Budget. - Science, 312: 1612-1613. 